\title{
Nurse effect and herbivory exclusion facilitate plant colonization in abandoned mine tailings storage facilities in north-central Chile
}

\author{
El efecto nodriza y la exclusión de herbivoría facilitan la colonización de plantas en \\ depósitos de relaves mineros abandonados en Chile centro-norte
}

\author{
JAIME G. CUEVAS ${ }^{1, *}$, SERGIO I. SILVA ${ }^{2}$, PEDRO LEÓN-LOBOS ${ }^{2,5} \&$ ROSANNA GINOCCHIO ${ }^{3,4}$ \\ ${ }^{1}$ Instituto de Investigaciones Agropecuarias, Oficina Técnica Los Ríos, Casilla 567, Valdivia, Chile \\ ${ }^{2}$ Banco Base de Semillas, Instituto de Investigaciones Agropecuarias, INIA-Intihuasi, Casilla 73, Vicuña, Chile \\ ${ }^{3}$ Departamento de Ecosistemas y Medio Ambiente, Facultad de Agronomía e Ingeniería Forestal, \\ Pontificia Universidad Católica de Chile, Av. Vicuña Mackenna 4860, Macul, Santiago, Chile \\ ${ }^{4}$ Centro de Investigación Minera y Metalúrgica, Av. Parque Antonio Rabat 6500 Vitacura, Santiago, Chile \\ ${ }^{5}$ Centro de Estudios Avanzados en Zonas Áridas, Colina el Pino s/n, La Serena, Chile \\ ${ }^{*}$ Corresponding author: jxcuevas@inia.cl
}

\begin{abstract}
Positive interactions among plants, such as the nurse effect, can attenuate environmental stress (e.g., drought) or reduce the intensity of perturbations (e.g., herbivory), thus enhancing the possibility of regeneration in natural systems. This study analyses the potential use of nurse plants for restoring artificial environments, such as mine hard-rock dumps. We evaluated seedling recruitment and survival in open areas and beneath the canopy of nurse shrubs, with and without grazing exclusion, on an abandoned copper tailings storage facility in north-central Chile. The nurse species was Baccharis linearis (Asteraceae), and seedling species were B. linearis, Haplopappus parvifolius (Asteraceae), Schismus arabicus (Poaceae), and several forb/grass taxa. A field survey showed that seedlings of all species were more abundant beneath the Baccharis shrub canopy coverage than in the open spaces between shrubs. Only Baccharis seedlings produced a significant difference. We found a decreasing sequence of seedling survival under the following conditions: beneath the Baccharis canopy with herbivore exclusion, beneath the canopy without exclusion, in the open field with exclusion, and finally, in the open field without exclusion. Substrates beneath shrubs had higher $\mathrm{P}$ and $\mathrm{K}$ levels at depths $<10 \mathrm{~cm}$ than substrates in open areas. Water content, substrate compaction, and plant diversity did not differ between microenvironments. Our results demonstrate the importance of both the nurse effect and herbivore exclusion in enhancing seedling establishment on abandoned mine tailings storage facilities in semi-arid north-central Chile. Thus shedding light upon the ecological restoration possibilities in such disturbed environments.
\end{abstract}

Key words: Baccharis linearis, Haplopappus parvifolius, hard rock waste, primary succession, survival analysis.

\section{RESUMEN}

Las interacciones positivas, tales como el efecto nodriza, pueden atenuar el estrés ambiental (e.g., sequía) o reducir la intensidad de una perturbación (e.g., herbivoría), aumentando la probabilidad de regeneración de plantas en los ecosistemas naturales. El presente estudio analiza el potencial de uso de plantas nodriza para la restauración de ambientes artificiales, como los depósitos de relaves mineros abandonados. Evaluamos el reclutamiento y sobrevivencia de plántulas bajo y fuera del dosel de arbustos nodrizas, así como con y sin la exclusión de herbívoros, sobre un depósito de relaves de cobre abandonado en la zona centro-norte de Chile. Se utilizó como especie nodriza a Baccharis linearis (Asteraceae). Las plántulas evaluadas para reclutamiento fueron de B. linearis, Haplopappus parvifolius (Asteraceae), Schismus arabicus (Poaceae) y otros taxa de hierbas dicotiledóneas o gramíneas. El muestreo en terreno demostró que las plántulas de todas estas especies fueron más abundantes bajo el dosel de Baccharis que en las áreas abiertas entre arbustos. Solo para las plántulas de Baccharis estas diferencias fueron significativas. A su vez, encontramos una reducción secuencial en la sobrevivencia de plántulas bajo las siguientes condiciones: bajo el dosel de Baccharis con exclusión de herbívoros, bajo el dosel sin exclusión, áreas abiertas con exclusión y, finalmente, en áreas abiertas sin exclusión de herbívoros. El sustrato bajo arbustos mostró mayor nivel de P y K a una profundidad $<10 \mathrm{~cm}$ en comparación con el sustrato de áreas abiertas. La compactación y el contenido de agua en el sustrato, así como la diversidad de plantas, no difirieron entre ambientes. Nuestros resultados demuestran la importancia del efecto nodriza y la exclusión de herbívoros en el establecimiento de plántulas, en los depósitos de relaves mineros en la zona semi-árida del centro-norte de Chile. De este modo, arroja luz sobre las posibilidades de restauración ecológica en tales ambientes perturbados.

Palabras clave: análisis de supervivencia, Baccharis linearis, desechos de rocas, Haplopappus parvifolius, sucesión primaria. 


\section{INTRODUCTION}

The metal mining industry has developed along with humankind for thousands of years (Jenkins 2004). In addition to the human wealth and welfare associated with this activity, it has generated intense environmental degradation through the production of a broad range of hard-rock residues, such as tailing storage facilities, heap leach piles, and smelter dust and slags (Asami 1988, Dudka \& Adriano 1997). Abandoned tailing storage facilities (TSFs), for instance, are a potential source of pollution given their high metal concentrations (Badilla-Ohlbaum et al. 2001, Frérot et al. 2006, Ginocchio et al. 2006). Loose tailings particulate matter is easily mobilized by wind, rain, and landslides, altering stream and soil quality, thus posing risks for crops, animal husbandry, wildlife, and human health (Petrisor et al. 2004, Mendez \& Maier 2008).

Once TSFs are abandoned, they dry out, particularly in arid and semiarid conditions. Even though they are extremely degraded, human-created environments, they represent new potential spaces for organisms that live in the surrounding areas to colonize. In fact, wild flora can very slowly establish itself in these degraded environments with no human assistance (Ginocchio et al. 2004, Frérot et al. 2006). In order for plants to colonize tailings they must overcome a diversity of abiotic challenges given the substrate's composition, such as poor macronutrient levels, lack of organic matter and structure, compaction, bad drainage, high temperatures, water stress, and the presence of toxic or highly acidic substances derived from mining activities (Choi \& Wali 1995). Furthermore, biotic factors also restrict the initial colonization, such as a sparse or absent vegetation coverage with scarce shade and wind-breaks (Ginocchio et al. 2004, Mendez \& Maier 2008). Positive interactions among plants, which facilitate species regeneration, have been described in natural environments (Callaway 1995, Bruno et al. 2003) and may help plants to colonize disturbed areas. One of the most documented examples of this facilitation is the nurse effect (Flores \& Jurado 2003, Padilla \& Pugnaire 2006), where a nurse species can benefit the germination, establishment and the overall performance of beneficiary plants found beneath its canopy. Nurse species can increase the soil's moisture, provide seedlings with protection against excessive sunlight, buffer extreme fluctuations in air and soil temperatures, and supply a higher amount of organic matter and macronutrients (Gutiérrez et al. 1993, Ginocchio et al. 2004). Moreover, a higher concentration of microbiota can aid in the nutrient cycling which occurs beneath these nurse shrubs (Aguilera et al. 1999). All of these variables contribute to successful recruitment at critical life stages in the plant's life cycle, such as the seed and seedling stages.

Herbivory is one of the main negative biotic interactions that can hinder plant regeneration in any kind of environment (Gutiérrez et al. 1997, Padilla \& Pugnaire 2006). The effect can be slight, or even beneficial for plants, as occurs in some grazing systems (Hodgson 1990, Briske 1996). On the contrary, when there are more herbivores than the carrying capacity of a particular environment, they can drastically restrict plant regeneration, especially if these animals are exotic to the community (Fuentes et al. 1986, Cuevas \& Le Quesne 2006). Nurse shrubs can mitigate this negative interaction. For example, in northcentral Chile goat herbivory is expressed as over-browsing in open sites; however, under the protection of spiny shrubs or cacti, established seedlings tend to be larger and are less attacked by herbivores than those growing outside in the open spaces between shrubs (Gutiérrez \& Squeo 2004). In this case, the facilitation operates through the exclusion of herbivores by the architecture of nurse plants. The nurse effect and herbivore pressure, long recognized as important phenomena in natural environments, have more recently been considered essential in degraded land restoration. For example, Castro et al. (2002, 2004) and Badano et al. (2009) showed that tree planting beneath shrubs had higher success rates than planting in open sites. Moreover, the first two studies challenged the prevailing paradigm that extant shrubby vegetation competes with planted trees. Although the herbivory component evaluated by Castro et al. (2004) was not detected as an important factor, herbivory has spatial and temporal variations (Austrheim et al. 2011) that must be addressed in any restoration project. 
In the case of abandoned mine sites, several studies have suggested that facilitation could be important for plant colonization (Choi \& Wali 1995, Cooke \& Johnson 2002, Ginocchio et al. 2004, Frérot et al. 2006). Therefore, the original contribution of this paper is specifically to test the key hypothesis that seedling survival and establishment in TSFs is higher beneath a shrub canopy protected from herbivory than in open sites with intense herbivore pressure. Validating this hypothesis will have the practical implication that nurse plants and their associated microenvironment should be employed in the design of better ecological restoration plans for these systems. Our objectives were to quantify patterns of natural plant recruitment in an abandoned TSF in the Chilean semi-arid zone, to determine how the nurse effect and herbivory influence seedling survival and establishment, and to characterize the substrate abiotic conditions as probable determinants of the observed patterns.

\section{METHODS}

\section{Study site and species}

The site selected for this study, Tambillos abandoned TSF $\left(30^{\circ} 11^{\prime} 56^{\prime \prime} \mathrm{S} ; 71^{\circ} 14^{\prime} 40^{\prime \prime} \mathrm{W}\right)$, is one of several TSFs of the Sociedad Contractual Minera Lolol located $30 \mathrm{~km}$ south of La Serena, Coquimbo Region, Chile. Tambillos is located in an area with a semi-arid Mediterranean climate with mean maximum temperatures $>30{ }^{\circ} \mathrm{C}$ in January and mean minimum temperatures of $3-4{ }^{\circ} \mathrm{C}$ in July (Vita et al. 1995). Rainfall is concentrated in the winter months, with an annual mean precipitation of $125 \mathrm{~mm}$, although this varies greatly year to year. The dry period has low relative air humidity and lasts 8 to 10 months (Vita et al. 1995). Tambillos TSF's total surface area is 3.6 ha and is the result of a typical alkaline flotation circuit of copper sulfide ores. Its metal content (in $\mathrm{g} \mathrm{kg}^{-1}$ ) is: $\mathrm{Cu} 1.35, \mathrm{Zn} \mathrm{0.37,} \mathrm{Fe} \mathrm{76.72,} \mathrm{and} \mathrm{Ca}$ 34.55. It was operated until 1986, after which it received no further treatment and was left as a completely exposed substrate.

The dominant vegetation type across the study area is inland steppe shrubland (Luebert \& Pliscoff 2006). Common species are the shrubs Baccharis linearis (R. et P.) Pers., B. marginalis DC., Pleocarphus revolutus D. Don, the suffrutescent (subshrub) Haplopappus parvifolius (DC.) A. Gray, and the tree Schinus molle L. Both $P$. revolutus and $H$. parvifolius are some of the species which define this vegetation type. The shrublands surrounding the TSF are strongly affected by intense animal browsing and harvesting by humans, which have led to a landscape of scattered, short shrub communities with a dense stratum of annual forbs and grasses (coverage $>60 \%$ ), due to seasonal rainfall (Squeo et al. 2001). On the contrary, in the TSF itself, the vegetation structure has been recovering well with no assistance since 1986 , with shrubs up to $2 \mathrm{~m}$ high, but with very scant forb/grass coverage.
We studied two of the most abundant species spreading within the TSF, Baccharis linearis (romerillo, $19 \%$ cover) and Haplopappus parvifolius (bailahuén, 1 $\%$ cover). Both species belong to the Asteraceae family. Baccharis linearis is a densely ramified Chilean native shrub 0.5-3.0 $\mathrm{m}$ tall. Haplopappus parvifolius is a Chilean endemic suffrutescent (subshrub) $<1 \mathrm{~m}$ in height. The longitudinal distribution of both species extends from the Coastal to the Andean Ranges while the latitudinal range of $B$. linearis stretches from the Atacama $\left(26^{\circ} 41^{\prime} \mathrm{S}\right)$ to the Los Ríos Regions (3952'S). Haplopappus parvifolius has a narrower distribution, only being found within the Atacama (28 $\left.34^{\prime} \mathrm{S}\right)$ and Coquimbo Regions (31 ${ }^{\circ} 19^{\prime}$ S) (Squeo et al. 2001). A clumped distribution pattern was found for $B$. linearis in the studied TSF, with 1320 individuals ha-1 (> $40 \mathrm{~cm}$ height).

\section{Natural recruitment}

In August, 2005 (winter), we evaluated the natural recruitment of all of the species found in the TSF in order to determine the distance from adult shrubs at which plant seedlings grew most abundantly. This month was chosen because it marked the end of this region's rainy season, and most species germinate in this period. We chose $B$. linearis as the putative nurse species because previous studies have documented its role as a pioneer species that serves as a recruitment foci for birddisseminated seeds and seedlings beneath the canopy of adults (Armesto \& Pickett 1985, Fuentes et al. 1986, Bustamante 1991).

We randomly selected 19 adult individuals of Baccharis (1.5-2 $\mathrm{m}$ tall; 0.9-4.4 $\mathrm{m}$ in diameter). This sample size was chosen as adequate, because a numerical simulation showed that the coefficient of determination and the associated probability for an exponential model of seedling distribution (see below) either stabilizes from $\mathrm{n}=10$ shrubs on $(B$. linearis seedlings) or is maximal for $\mathrm{n}=1$ to 4 (the other species) (data not shown).

From the centre of the shrub, we laid out a transect in the direction which allowed for a maximum length of $9 \mathrm{~m}$ and a width of $1 \mathrm{~m}(\mathrm{n}=19)$. We counted and identified all seedlings with a height $\leq 5 \mathrm{~cm}$ in the area within the transect. We also measured the distance between seedlings and the edge of the canopy for those established outside the canopy's shade. Due to variations in canopy diameter, areas sampled beneath the canopy were not exactly equivalent to $1 \mathrm{~m}^{2}$. To allow for comparisons with the outside plots, we expressed all densities as individual $\mathrm{m}^{-2}$.

\section{Nurse effect and herbivory}

There are several plant processes which nurse shrubs can affect, one of the main possibilities is their affecting seedling survival. Thus, we determined the seedling survival probability in each of the defined microenvironments, beneath/outside the canopy, and with/without herbivory. Galvanized mesh (openings $25 \times 20 \mathrm{~mm}$ ) was used as herbivory protection because the Baccharis canopy is unlikely to act as an herbivore exclusion given its architecture, which does not prevent animals from entering into its foliage. All sides of the experimental plots, including the top, were covered with the mesh (110 cm height) and it was buried $50 \mathrm{~cm}$ into the ground to exclude burrowing herbivores.

Seedlings were planted in $50 \times 50 \mathrm{~cm}$ plots, and plots were randomly distributed in the TSF beneath the Baccharis canopy and in the open field about $4 \mathrm{~m}$ from 
the canopy. The experiments were performed following a factorial arrangement; the combination of factors' levels resulted in four treatments: (i) seedlings beneath the Baccharis canopy with protection against medium and large herbivores (rabbits, hares, asses, goats, degus [a native rodent], and horses) (10 replicates); (ii) seedlings beneath the Baccharis canopy without protection against herbivores (10 replicates); (iii) seedlings in the open field with protection against herbivores (10 replicates); and (iv) seedlings in the open field without protection against herbivores (10 replicates).

We used $B$. linearis and $H$. parvifolius seedlings based on results of their natural recruitment, that is, because they produced the clearest decreasing trends in density at increasing distances from the shrub canopy. Seedlings were produced in a greenhouse in May, 2006 (autumn) from seeds collected in the same TSF. The propagation substrate was a mixture of surface tailings from the Tambillos TSF, natural soil, and domestic compost in a 3:2:1 volume ratio. Seedlings were transplanted to the field when they were around 3 months old (August, 9th 2006).

Each plot had 10 or 9 seedlings (Baccharis and Haplopappus, respectively) replicated by 10 , but each species was allocated to different plots. Seedlings were marked in the field with coloured wire to facilitate individual identification. Post-transplant stress was alleviated only once through irrigation with tap water (1 litre per experimental unit $=4 \mathrm{~mm}$ of precipitation) immediately after transplanting.

The first monitoring was eight days after transplanting and, after that, every 15-20 days up to 320 days after transplanting (June, 2007). Plant survival was evaluated at each field visit, and live plants were considered as those individuals with at least a portion of green coloration in their aerial organs. Repeated surveys of the same individuals discarded the possibility of misclassifying plants as dead.

\section{Substrate characterization}

We measured the substrate water volumetric content with a Theta probe (Delta-T Devices, United Kingdom), by using the device's "Mineral soil" option. This sensor measures this variable between depths of 0 and $6 \mathrm{~cm}$. We selected 10-20 random points in each microenvironment (beneath Baccharis canopy/open sites), in two sampling periods two months apart.

Substrate compaction was measured with a pocket penetrometer, with a sample size of 10 for each microenvironment. Specific sites for both kinds of measurements corresponded to those where experimental plantations were carried out.

In November, 2006 (spring), six random samples of superficial substrate $(0-20 \mathrm{~cm})$ were taken from each defined microenvironment (beneath/outside canopy) to analyse the nutrient content and other possible edaphic differences between the microhabitats. Sampling was carried out with a $9.7 \mathrm{~cm}$ diameter PVC tube. Samples were extracted every $5 \mathrm{~cm}(0-5 \mathrm{~cm}, 5-10 \mathrm{~cm}, 10-15 \mathrm{~cm}$, and $15-20 \mathrm{~cm}$ ) because nutrients may be differentially distributed according to depth (Havlin et al. 1999). A composite sample was produced for each depth and environment by mixing material obtained from all replicates and stored in airtight sealed plastic bags. We also collected all the available litter inside the PVC tubes, on the same November date, with the help of a brush. Litter was only found beneath the canopy. Substrate samples were analysed in accordance with the following methods: available N, N-Kjeldahl; P, Olsen; available $\mathrm{K}$, atomic absorption spectrophotometer; electrical conductivity and $\mathrm{pH}$ in water solution (1:2.5) following the methods described by Sadzawka et al. (2006); and organic matter through calcination (Sadzawka et al. 2006).

\section{Data analyses}

In order to represent the spatial recruitment pattern of non-planted seedlings, measured as seedling density and diversity as a function of distance to the centre of the nurse shrub, distribution frequency graphs with class intervals of $1 \mathrm{~m}$ were used. This square size (1 $\mathrm{m}^{2}$ due to the width of the transect) was appropriate for the scale of seedling distribution and abundance, and transect length. Density trends as a function of distance were adjusted to a negative exponential model given the shapes of the distribution frequencies. Moreover, the exponential curve is a common model for seed dispersal and seedling recruitment that has been used in many studies (e.g., Willson 1993, Bustamante 1995, Cuevas 2000). The regressions were computed through the Levenberg-Marquardt algorithm (Statistica 2.0 software).

Seedling diversity was calculated using the ShannonWiener-Weaver index. For open spaces between the shrubs, we separated density data into adjacent $1 \mathrm{~m}^{2}$ squares from the canopy boundary to the transect end, allowing the index calculation to be a function of distance from the canopy. To compare diversity among microenvironments, since the area sampled beneath the nurse shrubs was much smaller than the area outside the canopy, we randomly selected one $1-\mathrm{m}^{2}$ sampling square outside the canopy for each one of the 19 nurse shrubs. This allowed us to make Mann-Whitney comparisons of similar areas beneath/outside shrubs, and with the same sample size $(\mathrm{n}=17)$.

Survival curves were constructed by pooling survival data from the 10 replicates of each treatment and species and by applying Kaplan-Meier's method (Basu 1984). This procedure estimates the survival function directly from the continuous survival times: first statistical differences among all the curves were calculated with a Chi-square test. Second, if differences were detected, pairs of treatments were compared by the two-sample log-rank test. In order to test the final results without the influence of the survival curve shape a non-parametric three-way ANOVA was performed using the final survival data: the Scheirer-Ray-Hare extension of the KruskalWallis test (Sokal \& Rohlf 1995, p. 446) because data could not be normalized to satisfy ANOVA assumptions. Factors considered were species, microenvironment, herbivory, and their interaction.

The remaining variables were compared between microenvironments (beneath the canopy and outside the canopy) by means of two tailed t-tests. We used the arcsine or $\log$ transformation when needed to satisfy parametric assumptions. When assumptions were not met, Kruskal-Wallis or Mann-Whitney tests were used. A posteriori comparisons were carried out through the nonparametric Fisher's Least Significant Difference test (LSD, Conover 1980). For each of the 19 Baccharis shrubs, we pooled the seedlings found outside the canopy, allowing us to calculate a single density for every transect, which was compared with the respective densities beneath the shrubs. All analyses were carried out with Statistica 6.0 software, StatSoft Inc., Oklahoma, USA. 
RESULTS

\section{Natural recruitment}

We identified 13 plant species recruited within the Tambillos TSF. Two of these species were non-herbaceous (B. linearis and $H$. parvifolius) while the other eleven were forbs and grasses (Erodium cicutarium (L.) L'Hérit. ex Aiton, Pectocarya linearis (R. et P.) DC., Pennisetum clandestinum Hochst. ex Chiov, Plantago hispidula R. et P., Schismus arabicus Nees, Sonchus tenerrimus L.); there were also five unidentified species due to negligible development. Seedling density outside the shade of the canopy (summed for all species and all distances from the nurse shrub) was very low, with a mean density $( \pm$ standard error) of $10.7 \pm 4.1$ small plants $\mathrm{m}^{-2}(\mathrm{n}=19)$, meaning the soil between adult shrubs was almost bare. On the contrary, seedling density beneath the canopy reached a mean $( \pm$ standard error) of $41.7 \pm 13.9$ plants $\mathrm{m}^{-2}(\mathrm{n}=19)$ (t-test for log-transformed data; $\mathrm{t}_{36}=-2.523, \mathrm{P}=0.016$ ).

All species detected as seedlings decreased in density as the distance from the shrub canopy increased (Fig. 1). However, the pattern was stronger for Baccharis (negative exponential model; $\mathrm{r}^{2}=0.983, \mathrm{P}<0.0001$, Fig. 1A). The Haplopappus density pattern was similar to that of Baccharis, but the mean density of this species varied between 0 and 4.3 individuals $\mathrm{m}^{-2}\left(\mathrm{r}^{2}=0.797, \mathrm{P}=0.001\right.$, Fig. $\left.1 \mathrm{~B}\right)$.

Schismus arabicus was found to be the most abundant herb species in the tailing dump (Kruskal-Wallis test; $\mathrm{H}_{10}=91.2, \mathrm{P}<0.001$ for all possible comparisons between forbs and grasses when a posteriori, non-parametric Fisher's LSD test was applied). Although this species did not show as strong a pattern as the two previous species, its density also decreased from the centre of the shrub's canopy out into the open field, from 20 to 0 individuals $\mathrm{m}^{-2}$ (negative exponential model; $\mathrm{r}^{2}=0.677, \mathrm{P}=0.002$, Fig.
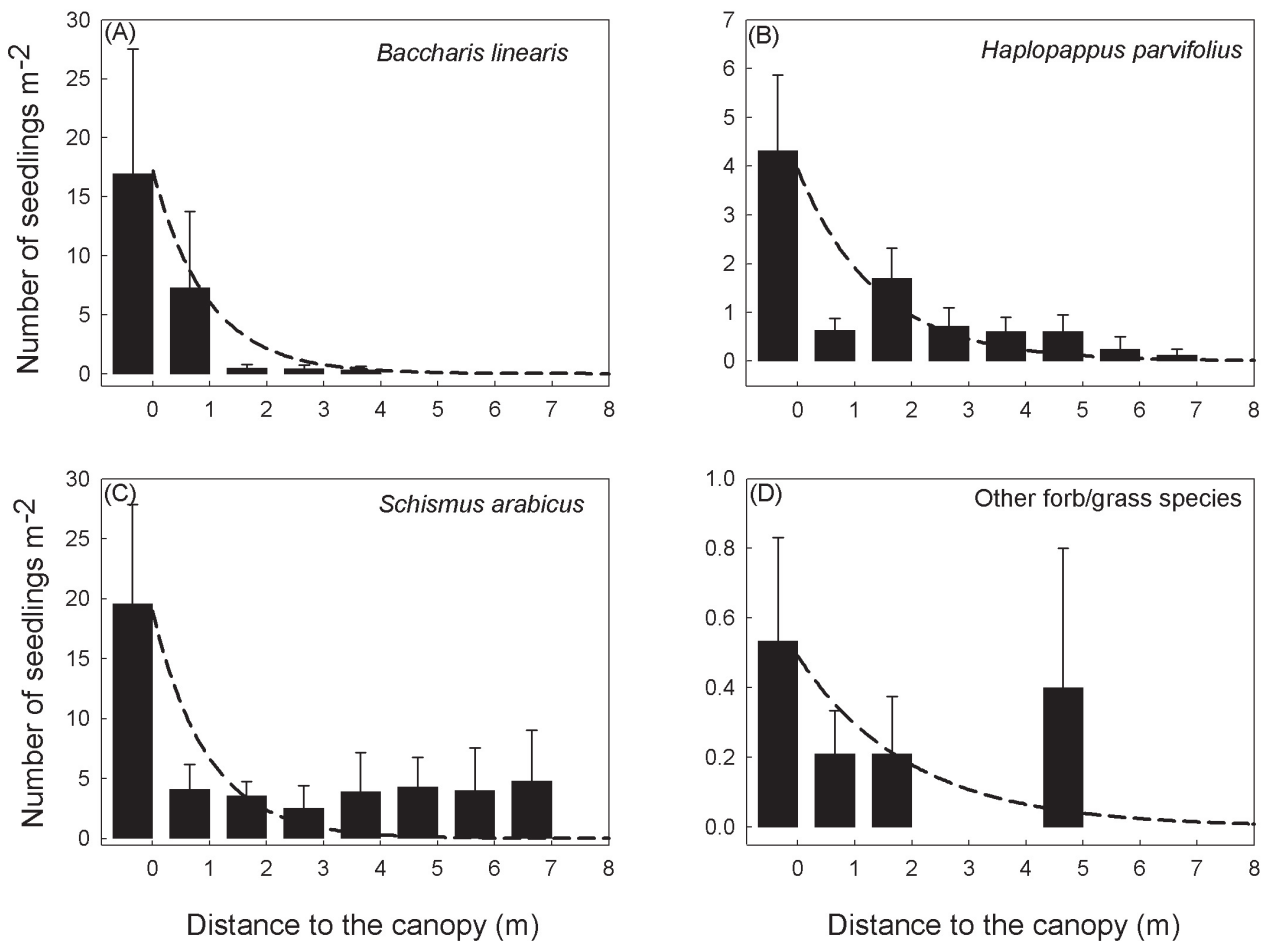

Fig. 1: Pattern of seedling density (mean $\pm \mathrm{SE} ; \mathrm{n}=19$ shrubs) at increasing distances from Baccharis linearis canopy boundary (point 0 is beneath the canopy) at the Tambillos tailing storage facility in the Coquimbo Region, Chile. The dashed line represents a negative exponential model.

Patrón de densidad de plántulas (promedio \pm EE; $\mathrm{n}=19$ arbustos) a distancias crecientes desde el borde del dosel de Baccharis linearis (el punto 0 está debajo del dosel), en el depósito de relaves Tambillos, Región de Coquimbo, Chile. La línea segmentada representa un modelo exponencial negativo. 
1C). No differences were observed 1 to $7 \mathrm{~m}$ from the canopy's edge. The remaining grass/ forb species exhibited very low densities, thus all were pooled to establish a density pattern which was noisier than the other species since some frequency bars produced null values (none of the 19 quadrats of the respective distance had a single seedling established $)\left(r^{2}=\right.$ $0.524, \mathrm{P}=0.014$, Fig. 1D). This makes it difficult to identify a trend in the data.

When comparing seedling density between microenvironments (beneath canopy/outside canopy), the results were the following: Baccharis seedling density was significantly higher beneath the canopy than outside in open sites (Mann-Whitney test; $\mathrm{U}=94.5, \mathrm{P}=0.012$, $\mathrm{n}=19$ ), while no differences were found for the other species $(\mathrm{U}>126, \mathrm{P}>0.112, \mathrm{n}=19)$. Seedling diversity as a function of distance from the nurse shrubs showed no clear trend (Fig. 2) since some inconsistencies were observed at certain distances (i.e., at 4 and $7 \mathrm{~m}$ from the shrubs). Moreover, the values of the Shannon diversity indexes were not significantly different for the microenvironments (MannWhitney test; $\mathrm{U}=98.5, \mathrm{P}=0.177, \mathrm{n}=17$ ).

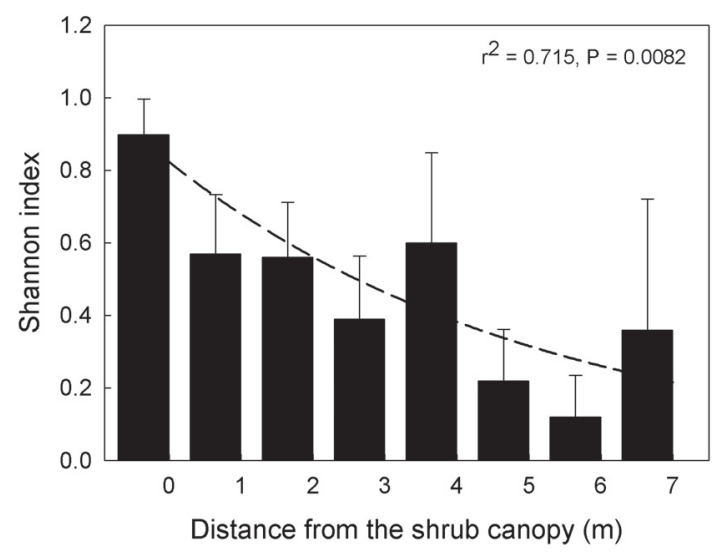

Fig. 2: Shannon diversity index as a function of seedling distance to the nurse shrub canopy (point 0 ). Mean \pm SE. Statistics correspond to a negative exponential model.

Índice de diversidad de Shannon como una función de la distancia de las plántulas al dosel del arbusto nodriza (punto $0)$. Promedio \pm EE. Las estadísticas corresponden a un modelo exponencial negativo.

\section{Nurse effect and herbivory}

Baccharis seedling survival decreased from the beginning of the experiment in all of the treatments (Fig. 3A). Survival curves were significantly different among treatments at $\mathrm{P}$ $<0.001$ (Chi-square test, $\mathrm{X}_{3}{ }_{3}=32.4$ ). Seedlings protected from herbivores located beneath the canopy showed the highest survival rate from the $42^{\text {nd }}$ day of the experiment until its close (35\%; log-rank test for the full period, $\mathrm{P}<0.002$, compared to the other three treatments). Treatments outside the canopy with exclusion (19\%) and beneath the canopy without exclusion (11\%) demonstrated the following highest survival rates. In spite of the differences between these two treatments
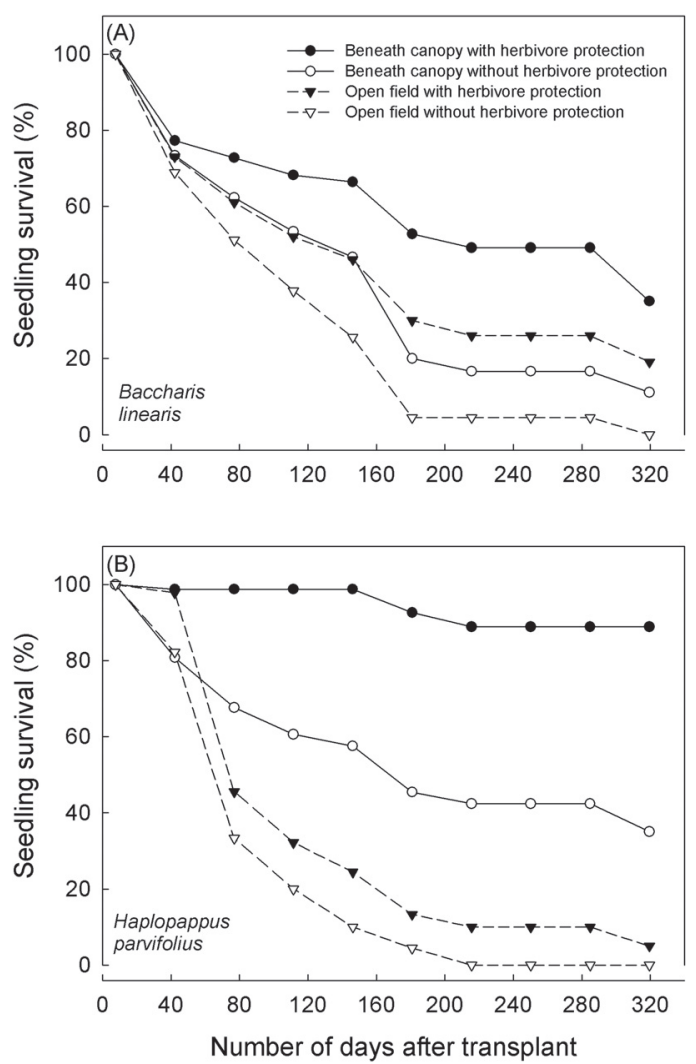

Fig. 3: Percentage of seedling survival after transplant at the Tambillos tailing storage facility in the Coquimbo Region, Chile. Curves were constructed according to Kaplan-Meier's method.

Porcentaje de sobrevivencia de plántulas, después del trasplante, en el depósito de relaves de Tambillos, Región de Coquimbo, Chile. Las curvas fueron construidas usando el método de Kaplan-Meier. 
after 146 days, they were no longer significant (log-rank test, $\mathrm{P}=0.404)$. However, these two treatments did significantly differ from the other two (log-rank test, $\mathrm{P}<0.002$ ). Finally, seedlings located in open sites without exclusion showed the highest mortality rates and all died before the end of the experiment. Thus, the survival rates in this treatment were significantly different from the other three (logrank test, $\mathrm{P}<0.001)$.

For Haplopappus, survival curves were significantly different among treatments at $\mathrm{P}<$ 0.001 (Chi-square test, $\mathrm{X}^{2}{ }_{3}=155.6$ ). All paired comparisons between survival curves were significantly different for the full monitoring period at $\mathrm{P}<0.001$ (log-rank test). For the first 42 days of the experiment, treatments with herbivore exclusion showed higher survival rates than those that were unprotected (Fig. 3B). After the 42nd day, treatments in the open field (with or without exclusions) exhibited a strong decrease in survival, especially towards the end of the experiment (after 320 days of treatment). Individuals exposed to herbivores outside the canopy did not survive more than 180 days. The highest survival rate occurred beneath the canopy with protection against herbivores $(90 \%)$, followed by the treatment beneath the canopy without exclusion (35\%), then that in the open field with exclusion (5
$\%)$, and finally that in the open field without exclusion (0\%).

The non-parametric three-way analysis applied to the final survival data confirmed that both the canopy's microenvironment along with herbivory significantly affected the seedlings' survival rates $\left(\mathrm{H}_{1}=35.24\right.$ and $\mathrm{H}_{1}=17.15$, respectively; both $\left.\mathrm{P}<0.0001\right)$. The species factor, as well as the remaining interactions, were not significant $\left(\mathrm{H}_{1}<1.22, \mathrm{P}>\right.$ $0.269)$. The only exception was the species $x$ the environment interaction $\left(\mathrm{H}_{1}=6.20, \mathrm{P}=0.013\right)$. This result was supported by the survival analysis, which showed that Haplopappus had a higher survival rate than Baccharis beneath the canopy (log-rank test, $\mathrm{P}<0.001$ ), while the opposite occurred in open sites protected from herbivores (log-rank test, $\mathrm{P}=0.027$ ). In the remaining treatment, no difference was detected between the species survival curves (log-rank test, $\mathrm{P}=0.097$ ).

\section{Substrate characterization}

The substrate's volumetric water content was very low on the first sampling date (September, 2006), both outside the canopy (mean $1 \%$ ) and beneath it $(2 \%)(\mathrm{n}=10)$ (Fig. $4 \mathrm{~A})$. However, no statistical difference between the two microenvironments was detected (t-test; $\mathrm{t}_{18}=1.51, \mathrm{P}=0.148$, data transformed with
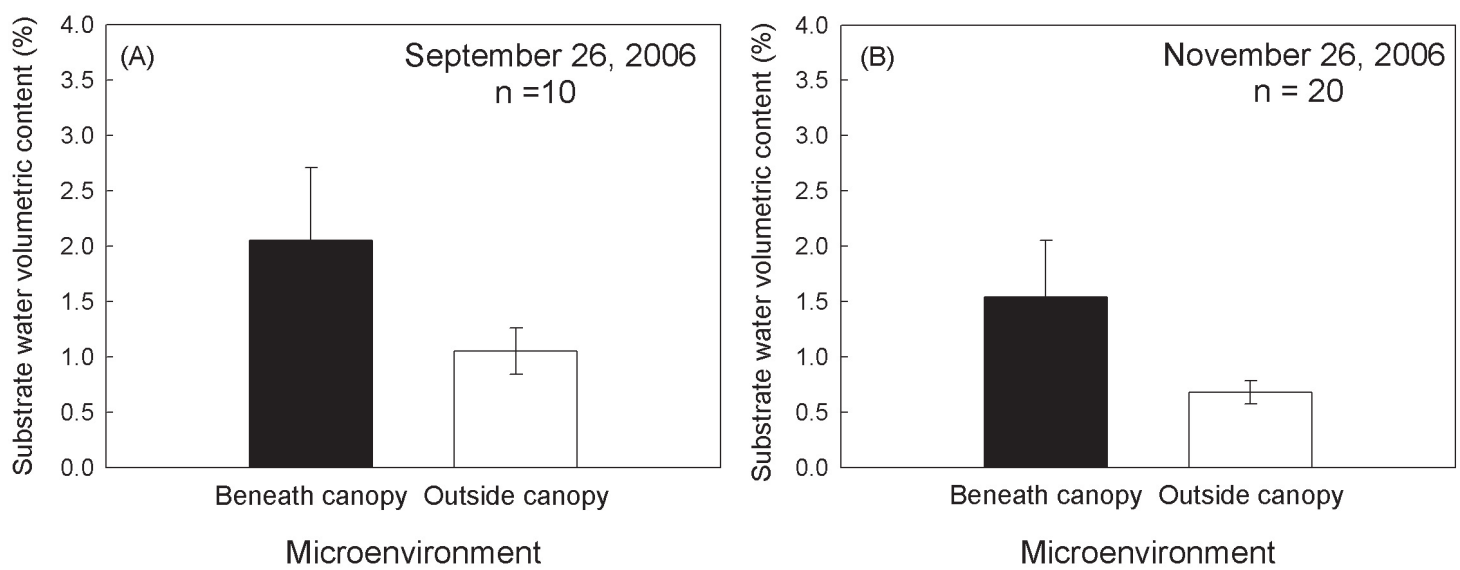

Fig. 4: Water volumetric content (mean $\pm \mathrm{SE}$ ) in the Tambillos tailing storage facility for two sampling dates and two microenvironments. $\mathrm{n}=$ sample size.

Contenido volumétrico de agua (promedio \pm EE) en el depósito de relaves de Tambillos para dos fechas de muestreo y dos condiciones microambientales. $\mathrm{n}=$ tamaño de muestra. 
the arcsine function). In order to avoid the restrictions of a low sample size, measurements were repeated two months later (November, 2006) with $\mathrm{n}=20$ (Fig. 4B). As expected mean values were slightly lower than in September (0.7-1.5\%, outside/beneath canopy, respectively). Once again, no significant differences were detected (Mann-Whitney test; $\mathrm{U}=165, \mathrm{P}=0.343, \mathrm{n}=20$ ).

Regarding substrate compaction, mean values ( \pm standard error) were very similar between microenvironments $(0.77 \pm 0.15$ vs. $0.92 \pm 0.20 \mathrm{~kg} \mathrm{~cm}-2$; outside canopy/beneath canopy) and no difference was detected between them ( $\mathrm{t}$-test; $\mathrm{t}_{18}=0.597, \mathrm{P}=0.558$ ).

Available potassium (K) achieved a maximum concentration of $75 \mathrm{mg} \mathrm{kg}^{-1}$ (Fig. $5 \mathrm{~A})$. Beneath the canopy, deeper layers of substrate showed a lower $\mathrm{K}$ content than upper layers. Available nitrogen $(\mathrm{N})$ content reached a maximum of $9 \mathrm{mg} \mathrm{kg}^{-1}$ at a depth of $15-20 \mathrm{~cm}$. Phosphorus (Olsen $\mathrm{P}$ ) reached a maximum of $5.3 \mathrm{mg} \mathrm{kg}^{-1}$ in the open sites, and organic matter content was very low irrespective of the microenvironment $(\leq 1 \%$ ) (Fig. 5B). Only K showed greater values beneath the canopy than in open sites (Mann-Whitney test, $\mathrm{U}=0.00, \mathrm{P}=$ $0.021, \mathrm{n}=4$ ). However, by inspecting Fig. $5 \mathrm{~B}$, we found that $\mathrm{P}$ outside the canopy increased with depth, while no similar trend was detected beneath the canopy. These patterns mean there was a higher $\mathrm{P}$ concentration beneath the canopy than outside it for depths $\leq 10 \mathrm{~cm}$. Below $10 \mathrm{~cm}$, the trend is reversed, which explains the absence of statistical differences between microenvironments.

Litter was only found beneath Baccharis canopies (mean $=162 \mathrm{~g} \mathrm{~m}^{-2}$ ). We observed that electrical conductivity and $\mathrm{pH}$ were not significantly different between microenvironments (beneath vs. outside the canopy), with a range from 0.9 to $1.4 \mathrm{mS} \mathrm{cm}^{-1}$ and from 7.6 to 7.9 , respectively (t-test; $\mathrm{t}_{6}<$ $0.254, \mathrm{P}>0.808)$.

\section{DISCUSSION}

\section{Natural recruitment}

Thirteen species were found to be naturally recruiting within the Tambillos TSF, only two of which were non-herbaceous (B. linearis and $H$. parvifolius). Both showed exponential
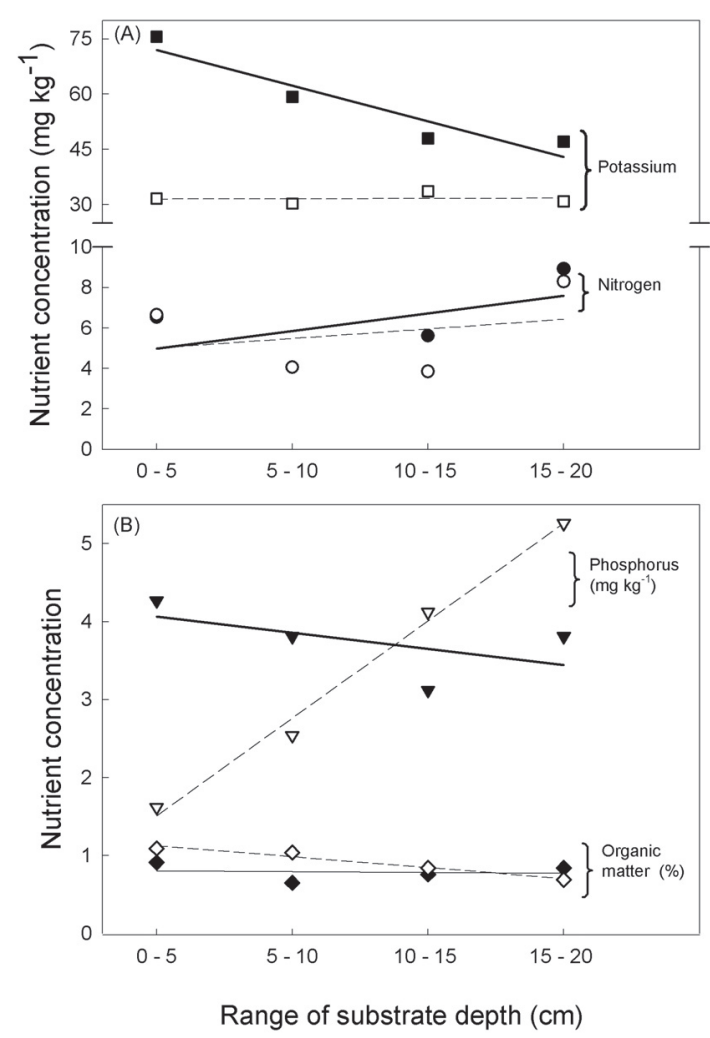

Fig. 5: Nutrient levels beneath Baccharis linearis shrubs (black symbols) and in open areas (white symbols) at the Tambillos tailing storage facility in the Coquimbo Region, Chile.

Niveles de nutrientes bajo arbustos de Baccharis linearis (símbolos negros) y en áreas abiertas (símbolos blancos) en el depósito de relaves de Tambillos, Región de Coquimbo, Chile.

trends of decreasing density at an increasing distance from the centre of the nurse shrub (B. linearis), but the pattern was strongest for $B$. linearis. The remaining taxa, mostly exotic and annual forb/grasses (Squeo et al. 2001), also demonstrated the same significant pattern, but the smaller explained variation and the frequency distribution shapes suggest that these herb species have a more generalist pattern of density. In fact, $B$. linearis was the only species that had a significantly higher density beneath the canopy than in open spaces. The other species probably behave as opportunistic invasive species (Noble 1989, Rejmánek \& Richardson 1996), but they do also profit from the shading effect provided by the nurse shrubs. Gómez-Aparicio (2009), based on a meta-analysis of several hundreds 
of experimental cases, also concluded that the ecological interactions were neutral or even negative (competition) when herbs are the species which receive protection from nurse trees and shrubs.

The seedling diversity pattern, as a function of distance from the canopy, also suggests that shrubs provide the conditions necessary for the existence of a more diverse assemblage beneath the canopy than in the open sites. However, since the transects were not established in one consistent direction (i.e., northwards vs. southwards), seedlings may have received significantly different amounts of shade protection. This would imply an absence of statistical differences in diversity when comparing the two microenvironments studied.

The spatial pattern exhibited by the seedlings can be explained, at least in part, by differential seed rain and seedling survival patterns. In spite of the fact that we did not evaluate seed rain, floral and vegetative remnants were concentrated beneath the Baccharis canopy $\left(162 \mathrm{~g} \mathrm{~m}^{-2}\right)$ versus 0 in open sites.

\section{Seedling survival}

For Haplopappus, at the start of the study, the herbivory effect was more important than the microenvironment effect provided by the canopy. This suggests that the microclimatic conditions were similar in the two microenvironments (beneath and outside the canopy) before the end of September, and, therefore, did not cause differential seedling mortality. The pattern was reversed on the $42^{\text {nd }}$ day of the experiment, until its end. In the case of $B$. linearis, the slight difference in this species' survival among treatments for the first 42 days of the experiment suggests that the initial mortality was a post-transplant effect rather than a treatment effect.

Higher seedling survival beneath the canopy may be partially due to more favourable nutritional conditions in this microhabitat than in open areas. Although nutrient levels in TSFs are low or very low compared to normal soils (Salisbury \& Ross 1992), we found that K and $\mathrm{P}$ levels were higher beneath the canopy than in open areas at the upper substrate horizons. This difference may be due to a higher litter accumulation supplied by standing vegetation on soils. Moreover, the decreasing (or inexistent) trends in depth detected for $\mathrm{K}$, organic matter and $\mathrm{N}$ were the same as those expected for normal soils (Havlin et al. 1999). For $\mathrm{P}$, the increase in concentration in relation to depth is rather atypical, but we must keep in mind that mineral patterns may also depend on the temporal fluctuations in the quality of the material processed by the mining facilities.

The substrate's physical properties, such as water content and compaction, did not differ between microenvironments. It is likely that the great variance beneath the canopy, along the low absolute differences in mean values of both variables, made the detection of significant effects difficult. Continuous measurements of substrate variables with datalogger systems would be a good way to more precisely assess possible differences beneath/outside the canopy.

Sites that were fully exposed to environmental conditions were particularly prone to seedling death. For example, the movement of tailing particles by wind results in seedlings being buried under very hot particles, particularly in the spring and summer months (personal observations). During the experiment, this problem was especially relevant for Haplopappus seedlings since they were shorter (12.1 to $17.6 \mathrm{~mm}$ ) than Baccharis seedlings (16.1 to $44.6 \mathrm{~mm}$ ) (data not shown; $\mathrm{P}<0.050$ for most of the study period, Mann-Whitney test). As previously stated, the herbal coverage both within and outside the experimental survival plots was very low, decreasing the possibility of competition with the planted seedlings as a causal factor for the patterns shown.

Our study also showed that herbivory by vertebrates negatively affects the seedling survival of both species. Animals responsible for killing seedlings were probably rabbits (which were sighted, as well as their feces and burrows), and horses (trampling). However, other herbivores may have also contributed to mortality, such as insects entering through the exclusions, thus causing partial or full defoliation (personal observations). A final observation supporting our findings was carried out in May, 2011, four years after the last evaluation of seedling survival: both Baccharis and Haplopappus seedlings had surpassed the wire protections in both 
microenvironments (> $60 \mathrm{~cm}$ high) and were absent in non-excluded sites found outside the canopy. We were unable to carry out a more detailed assessment because most of the protections were damaged since several years had passed since the start of the experiment.

\section{Comparison with related studies}

The results for the spatial pattern of Baccharis are consistent with Ginocchio et al. (2004) and Larrea-Alcázar et al. (2005) who reported higher seedling densities beneath shrubs than in open spaces in other semi-arid regions. Regarding seed dispersal, the concentration of floral and vegetative remnants near a mother plant is a typical result for abiotically dispersed species (Willson 1993, Bustamante 1995, Cuevas 2000). Moreover, species which have plumose achenes, such as those belonging to the Asteraceae family, are easily dispersed by the wind towards vegetation patches (Flores \& Jurado 2003) where wind speed is lower (Ginocchio et al. 2004). Choi \& Wali (1995) have already suggested the role of nurse species as traps for seeds dispersed by the wind in iron-mine tailings in the United States. The interaction caused by insect herbivory in sclerophyllous shrublands in central Chile has also been previously described (Fuentes et al. 1981, Fuentes et al. 1987).

In summary, our results are consistent with Gómez-Aparicio et al. (2004) and GómezAparicio (2009) who found that shrubs are promising candidates for restoration efforts, both as nurse and target plants.

\section{Concluding remarks}

The greater seedling survival beneath the canopy was a likely determinant for the seedling spatial pattern of the two main species found in the tailing dump studied, along with seed rain, which is expected to be concentrated beneath the canopy. The nurse effect provided by Baccharis ensured the regeneration of its own seedlings as well as those of Haplopappus. Higher nutrient accumulation beneath the canopy was a probable mechanism of the nurse effect. A strong herbivory component was also present, which partially determined the decrease in plant survival. These findings support our hypothesis.
ACKNOWLEDGMENTS: We thank the Sociedad Contractual Minera Lolol for the facilities provided to develop this study. We also thank Ismael Jiménez and Marcos Acosta for their help in plant propagation, greenhouse maintenance, and for their valuable field assistance. We are grateful to Rodrigo Vargas for his help in the spatial pattern determination. Further thanks go to Marcelo Rosas, Ana Sandoval, Lohengrin Cavieres, and Leonardo Bacigalupe for their comments on earlier versions of this paper. Three anonymous reviewers made valuable suggestions to the original manuscript. This research was funded by CORFO's Innova Chile through the 04CR9IXD-01 grant.

\section{LITERATURE CITED}

AGUILERA LE, JR GUTIÉRREZ \& PL MESERVE (1999) Variation in soil micro-organisms and nutrients underneath and outside the canopy of Adesmia bedwellii (Papilionaceae) shrubs in arid coastal Chile following drought and above average rainfall. Journal of Arid Environments 42: 61-70.

ARMESTO JJ \& STA PICKETT (1985) A mechanistic approach to the study of succession in the Chilean matorral. Revista Chilena de Historia Natural 58: 9-17.

ASAMI T (1988) Soil pollution by metals from mining and smelting activities. In: Salomons $W$ \& U Forstner (eds) Chemistry and biology of solid waste: Dredged material and mine tailings: 144169. Springer-Verlag, Berlin, Germany.

AUSTRHEIM G, EJ SOLBERG \& A MYSTERUD (2011) Spatio-temporal variation in large herbivore pressure in Norway during 1949-1999: has decreased grazing by livestock been countered by increased browsing by cervids? Wildlife Biology 17: 286-298.

BADANO EI, D PÉREZ \& CH VERGARA (2009) Love of nurse plants is not enough for restoring oak forests in a seasonally dry tropical environment. Restoration Ecology 17: 571-576.

BADILLA-OHLBAUM R, R GINOCCHIO, PH RODRÍGUEZ, A CÉSPEDES, S GONZÁLEZ, HE ALLEN \& GE LAGOS (2001) Effect of soil copper content on copper load of selected crop plants in central Chile. Environmental Toxicology and Chemistry 20: 2749-2757.

BASU AP (1984) Censored data. In: Krishnaiah PR \& PK Sen (eds) Handbook of Statistic 4. Nonparametric methods: 551-578. Elsevier Science Publishers, Amsterdam, The Netherlands.

BRISKE DD (1996) Chapter 2: Strategies of plant survival in grazed systems: a functional interpretation. In: Hodgson J \& AW Illius (eds) The ecology and management of grazing systems: 33-67. CAB International, Wallingford, UK.

BRUNO JF, JJ STACHOWICZ \& MD BERTNESS (2003) Inclusion of facilitation into ecological theory. Trends in Ecology \& Evolution 18: 119-125.

BUSTAMANTE RO (1991) Clonal reproduction and succession: the case of Baccharis linearis in the Chilean matorral. Medio Ambiente (Chile) 11: 43-47.

BUSTAMANTE R (1995) Depredación de semillas en bosques templados de Chile. In: Armesto JJ, C Villagrán \& M Kalin-Arroyo (eds) Ecología de los bosques nativos de Chile: 265-278. Editorial Universitaria, Santiago, Chile. 
CALLAWAY RM (1995) Positive interactions among plants. Botanical Review 61: 306-349.

CASTRO J, R ZAMORA, JA HÓDAR \& JM GÓMEZ (2002) Use of shrubs as nurse plants: a new technique for reforestation in Mediterranean mountains. Restoration Ecology 10: 297-305.

CASTRO J, R ZAMORA, JA HODAR, JM GOMEZ \& L GÓMEZ-APARICIO (2004) Benefits of using shrubs as nurse plants for reforestation in Mediterranean mountains: a 4-year study. Restoration Ecology 12: 352-358.

CHOI YD \& MK WALI (1995) The role of Pannicum virgatum (switch grass) in the revegetation of iron-mine tailings in northern New York. Restoration Ecology 3: 123-132.

CONOVER WJ (1980) Practical nonparametric statistics. John Wiley and Sons, New York, USA.

COOKE A \& MS JOHNSON (2002) Ecological restoration of land with particular reference to the mining of metals and industrial minerals: a review of theory and practice. Environmental Reviews 10: $41-71$.

CUEVAS JG (2000) Tree recruitment at the Nothofagus pumilio alpine timberline in Tierra del Fuego, Chile. Journal of Ecology 88: 840-855.

CUEVAS JG \& C LE QUESNE (2006) Low vegetation recovery after short-term cattle exclusion on Robinson Crusoe Island. Plant Ecology 183: 105124.

DUDKA S \& DC ADRIANO (1997) Environmental impacts of metal ore mining and processing: a review. Journal of Environmental Quality 26: 590-602.

FLORES J \& E JURADO (2003) Are nurse-protégé interactions more common among plants from arid environments? Journal of Vegetation Science 14: 911-916.

FRÉROT H, C LEFÉBVRE, W GRUBER, C COLLIN, A DOS SANTOS \& J ESCARRÉ (2006) Specific interactions between local metallicolous plants improve the phytostabilization of mine soil. Plant and Soil 282: 53-65.

FUENTES ER, A POAINI \& JD MOLINA (1987) Shrub defoliation in the Chilean matorral: what is its significance? Revista Chilena de Historia Natural 60: 276-283.

FUENTES ER, J ETCHEGARAY, ME ALJARO \& G MONTENEGRO (1981) Shrub defoliation by matorral insects. In: Di Castri F, DW Goodall \& RL Specht (eds) Mediterranean-type shrublands: 345-359. Elsevier Scientific Publishing Co., Amsterdam, The Netherlands.

FUENTES ER, AJ HOFFMANN, A POIANI \& MC ALLIENDE (1986) Vegetation change in large clearings: patterns in the Chilean matorral. Oecologia 68: 358-366.

GINOCCHIO R, G CARVALLO, I TORO, E BUSTAMANTE, Y SILVA \& N SEPÚLVEDA (2004) Micro-spatial variation of soil metal pollution and plant recruitment near a copper smelter in Central Chile. Environmental Pollution 127: 343-352.

GINOCCHIO R, P SÁNCHEZ, LM DE LA FUENTE, I CAMUS, E BUSTAMANTE, Y SILVA, P URRESTARAZU, JC TORRES \& P RODRÍGUEZ (2006) Agricultural soils spiked with copper mine wastes and copper concentrate: implications for copper bioavailability and bioaccumulation. Environmental Toxicology and Chemistry 25: 712-718.
GÓMEZ-APARICIO L (2009) The role of plant interactions in the restoration of degraded ecosystems: a meta-analysis across life forms and ecosystems. Journal of Ecology 97: 1202-1214.

GÓMEZ-APARICIO L, R ZAMORA, JM GÓMEZ, JA HÓDAR, J CASTRO \& E BARAZA (2004) Applying plant facilitation to forest restoration: a meta-analysis of the use of shrubs as nurse plants. Ecological Applications 14: 1128-1138.

GUTIÉRREZ JR \& FA SQUEO (2004) Importancia de los arbustos leñosos en los ecosistemas semiáridos de Chile. Ecosistemas (España) 13: 36-45.

GUTIÉRREZ JR, PL MESERVE, LC CONTRERAS, H VÁSQUEZ \& FM JAKSIC (1993) Spatial distribution of soil nutrients and ephemeral plants underneath and outside the canopy of Porlieria chilensis shrubs (Zygophyllaceae) in arid coastal Chile. Oecologia 95: 347-352.

GUTIÉRREZ JR, PL MESERVE, S HERRERA, LC CONTRERAS \& FM JAKSIC (1997) Effects of small mammals and vertebrate predators on vegetation in the Chilean semiarid zone. Oecologia 109: 398-406.

HAVLIN JL, JD BEATON, SL TISDALE \& WL NELSON (1999) Soil fertility and fertilizers. Prentice Hall, Upper Saddle River, New Jersey, USA.

HODGSON J (1990) Grazing management. Science into Practice. Longman Handbooks in agriculture, Harlow, Essex, UK.

JENKINS H (2004) Corporate social responsibility and the mining industry: conflicts and constructs. Corporate Social Responsibility and Environmental Management 11: 23-34.

LARREA-ALCÁZAR DM, RP LÓPEZ \& D BARRIENTOS (2005) The nurse-plant effect of Prosopis flexuosa D.C. (Leg-Mim) in a dry valley Bolivian Andes. Ecotropicos (Venezuela) 18: 89-95.

LUEBERT F \& P PLISCOFF (2006) Sinopsis bioclimática y vegetacional de Chile. Editorial Universitaria, Santiago, Chile.

MENDEZ MO \& RM MAIER (2008) Phytostabilization of mine tailings in arid and semiarid environments. An emerging remediation technology. Environmental Health Perspectives 116: 278-283.

NOBLE I (1989) Attributes of invaders and the invading process: terrestrial and vascular plants. In: Drake JA, HA Mooney, F di Castri, RH Grove, KJ Kruger, M Rejmánek \& M Williamson (eds) Biological invasions, a global perspective: 301-313. Scope 37, Wiley, Chichester, United Kingdom.

PADILLA FM \& FI PUGNAIRE (2006) The role of nurse plants in the restoration of degraded environments. Frontiers in Ecology and the Environment 4: 196-202.

PETRISOR IG, D DOBROTA, K KOMNITSAS, I LAZAR, JM KUPERBERG \& M SERBAN (2004) Artificial inoculation-perspectives in tailings phytostabilization. International Journal of Phytoremediation 1: 1-15.

REJMANEK M \& DM RICHARDSON (1996) What attributes make some plant species more invasive? Ecology 77: 1655-1661.

SADZAWKA A, M CARRASCO, R GREZ, M MORA, H FLORES \& A NEAMAN (2006) Métodos de análisis recomendados para los suelos de Chile. Serie Actas INIA No. 34. Instituto de Investigaciones Agropecuarias, Santiago, Chile.

SALISBURY FB \& CW ROSS (1992) Plant Physiology. Wadsworth Publishing Company, Belmont, California, USA. 
SOKAL RR \& FJ ROHLF (1995) Biometry. The principles and practice of statistics in biological research. Third edition. WH Freeman and Company, New York, USA.

SQUEO FA, G ARANCIO \& JR GUTIÉRREZ (eds) (2001) Libro rojo de la flora nativa y de los sitios prioritarios para su conservación: Región de Coquimbo. Ediciones Universidad de La Serena, La Serena, Chile.

Editorial responsibility: Audrey A. Grez

Received June 12, 2012; accepted December 28, 2012
VITA A, MT SERRA, I GREZ, M GONZALEZ \& DA OLIVARES (1995) Intervenciones silviculturales en espino (Acacia caven (Mol.)) en la zona árida de Chile. Revista Ciencias Forestales (Chile) 10: 51-62.

WILLSON MF (1993) Dispersal mode, seed shadows, and colonization patterns. Vegetatio 107: 261-280. 